\title{
A NEW TRUFFLE SPECIES ADDITION, Tuber macrosporum Vittad., TO TURKISH MYCOTA
}

\author{
Hasan Hüseyin DOĞAN \\ Selçuk University, Science Faculty, Biology Department, Campus, Konya, TURKEY \\ hhuseyindogan@yahoo.com ORCID iD: orcid.org/0000-0001-8859-0188
}

Cite this article as:

Doğan H.H. 2021. A new truffle species addition, Tuber macrosporum Vittad., to Turkish mycota. Trakya Univ J Nat Sci, 22(2): 139-146, DOI: $10.23902 /$ trkjnat.873651

Received: 03 February 2021, Accepted: 15 May 2021, Online First: 02 June 2021, Published: 15 October 2021

Edited by:

Neveen S.I. Geweely

Key words:

Hypogeous fungi

New record

Truffle

Tuber macrosporum

Turkey

\begin{abstract}
Tuber P. Micheli ex F.H. Wigg. species have always attracted people's attention, with their high diversity, culinary and economic interest, strong aromas as well as the importance of plant ecosystem and animal nutrition. Interest in truffle species has been increasing in recent years in Turkey. Although some truffle species have been known previously in Turkey, many species are yet to be identified. Tuber macrosporum Vittad. samples were collected from Edirne and Tekirdağ regions in 2017 in a field study conducted to find new truffle species. Tuber macrosporum samples were firstly identified by macro and microscopic features, and this result was supported as $99 \%$ by DNA analyses when compared to GenBank.

A short description of the newly reported species is given along with its macro and microphotographs, and spore images taken by a scanning electron microscope (SEM). Additionally, ITS based evolutionary history of the species is provided with phylogenetic trees.

Özet: Tuber P. Micheli ex F.H. Wigg. (trüf) türleri, güçlü aromaları, gastronomik ve ekonomik önemleri, yüksek çeşitlilikleri, bitki ekolojisi ve hayvan beslenmesinde olan önemleri ile her zaman insanların ilgisini çekmiştir. Türkiye'de trüf mantarı türlerine olan ilgi son yıllarda artmaktadır. Türkiye'de daha önce bazı trüf mantarı türleri bilinmesine rağmen, pek çoğu da henüz tanımlanmamıştır. Yeni trüf mantarı türlerinin bulunması amacıyla 2017 yılında Edirne ve Tekirdağ bölgelerinden Tuber macrosporum Vittad. örnekleri toplanmıştır. Tuber macrosporum örnekleri ilk olarak makro ve mikroskobik özellikleriyle tanımlanmış ve bu sonuç DNA analizleri ile GenBank'a göre \% 99 olarak desteklenmiştir.

Yeni rapor edilen türün kısa bir tanımı, makro ve mikro fotoğrafları ve taramalı elektron mikroskobu (SEM) ile alınan spor görüntüleri ile birlikte verilmiştir. Ek olarak, türün ITS'e dayalı evrimsel geçmişi filogenetik ağaçla verilmiştir.
\end{abstract}

\section{Introduction}

Tuber P. Micheli ex F.H. Wigg. species (Ascomycetes) are commonly referred to as "true truffles" and the other hypogeous truffles species in Ascomycetes or Basidiomycetes are known as "false truffles'. Truffles (Tuber spp.) make mycorrhizal associations with trees within gymnosperms and angiosperms. Several Tuber species, as in the case of $T$. macrosporum Vittad. (the smooth black truffle), are highly appreciated for their flavours. Due to the high sale price and being a species in demand in the truffle market, T. macrosporum is either sold mixed with $T$. eastivum (Wulfen) Spreng. or T. aestivum is also sold as $T$. macrosporum to amateur consumers.

Turkey can be characterized by different ecological regions and floral and rich genetic diversity, as an outcome of its particular geographical location and structure. This biological richness is also pronounced for mushrooms, as well as other organisms, and Turkey hosts a large number of mushroom species. After the broad cooperation of Turkish mycologists, A Checklist of the Fungi of Turkey was published in 2020 (Sesli et al. 2020). According to this checklist, a total of 5865 fungal taxa including 2782 of Basidiomycota, 2728 of Ascomycota, 282 of Myxomycota, 2 of Chytridiomycota, 33 of Oomycota, and 38 of Zygomycota have been listed in Turkey. Truffle species are among the most preferred mushrooms in Europe that provide economic income with their unique aroma and taste. Some of the exclusive and special restaurants in Europe specialize in truffle dishes and are especially preferred. Aromatic fragrances from truffle species are also evaluated for different purposes as 
oil with truffle, cheese with truffle, foods with truffle etc. When considering the importance of truffle species in the world and especially in Europe, to be a commercial potential in Turkey is inevitable. Significant increases in the number of truffle species and their distribution areas in Turkey were revealed by taxonomic studies conducted over the last decade, which led to a significant increase in the number and distribution areas of truffle species. Öztürk et al. (1997), reported Tuber brumale Vittad. for the first time from the Niğde province in Turkey in the first taxonomic study performed on truffles. More recently, T. borchii Vittad. was determined by Kaya (2009) in Kahramanmaraş. Tuber aestivum, $T$. mesentericum Vittad. and T. nitidum Vittad. were determined by Castellano \& Türkoğlu (2012) from Denizli province. In the following years, studies on truffle species in the country increased and more species were reported from various parts of the country [T. aestivum from Denizli, Konya (Gezer et al. 2014, Türkoğlu et al. 2015, Alkan et al. 2018); T. borchii Vittad. from Aydın, Denizli, Muğla, Samsun, Tekirdağ (Gezer et al. 2014, Elliot et al. 2016); T. brumale from Denizli, Niğde, Osmaniye, Samsun (Türkoğlu \& Castellano 2014, Gezer et al. 2014, Şen et al. 2016); T. excavatum Vittad. from Artvin, Denizli, Trabzon (Türkoğlu \& Castellano 2014, Şen et al. 2016, Uzun \& Yakar 2018); T. fulgens Quél from Kirklareli (Akata et al. 2020); T. mesentericum Vittad. from Denizli (Türkoğlu \& Castellano 2014); T. nitidum Vittad. from Burdur, Kastamonu, Osmaniye (Türkoğlu \& Castellano 2014); T. rufum Pollini from Antalya, Aydın, Bolu, Burdur, Denizli, Muğla, Kastamonu, Konya, Osmaniye (Gezer et al. 2014, Türkoğlu \& Castellano 2014, Türkoğlu et al. 2015, Şen et al. 2016); T. ferrugineum Vittad. from Antalya, Aydın, Denizli, Muğla (Elliot et al. 2016, Şen et al. 2016); T. puberulum Berk. \& Broome from Denizli (Elliot et al. 2016)].

So far studies in Turkey reported the presence of 10 truffle species in the country, and with the present study, T. macrosporum is added to the Turkish mycobiota as the $11^{\text {th }}$ species.

\section{Materials and Methods}

\section{Macro and microscopic study}

Truffle samples were collected in Thrace region of Turkey in 2017 with the help of specially trained dogs. Their colour photographs were taken and brought to the laboratory for microscopic examinations. The photographs of the spores and the tissues were taken with a Leica DM 3000 binocular microscope and calculations were done with the Leica software program. SEM (Scanning electron microscope) photographs were also taken from the asci and ascospores. For spore measurings, an average of 20 different spores was considered. Melzer reagent and $5 \% \mathrm{KOH}$ were used as the investigation medium. The samples, whose diagnoses were completed and dried, are stored in the Fungarium of Selçuk University Mushroom Application and Research Center in Konya.
For macroscopic and microscopic studies Breitenbach \& Kränzlin (1983), Pegler et al. (1993), Astier (1998), Medardi (2006, 2012), Montecchi \& Sarasini (2000), Gori (2005), Trappe et al. $(2007,2009)$ and Thompson (2013) were followed.

Molecular study

\section{DNA extraction}

Total DNA was extracted from dried fruit body tissue by using DNeasy Plant Mini Kit (Qiagen, USA) following the manufacturer's protocol. The quality of the DNA was checked based on electropherogram in 1\% TBE-agarose gel. Polymerase chain reaction (PCR) amplification and sequencing amplification of the ITS region of the template DNA was performed using the primers ITS1 and ITS4 (White et al. 1990).

The PCR product was purified using A\&A Biotechnology (Gdynia). A Clean-up kit was used following the manufacturer's protocol before the sequencing. The sequences of $T$. macrosporum were deposited at GenBank (National Center for Biotechnology Information, NCBI). For the molecular phylogeny, the sanger reads obtained from ITS1/ITS4 were assembled using Bioedit version 7.2 and BLAST analyses were performed with the assembled sequences for the identity rate search. The assembled sequences and the nucleotide sequences of the retrieved in-group and out-group members were aligned using the ClustalW algorithm of MEGAX software (Kumar et al. 2018). The phylogenetic trees demonstrating the evolutionary history of HHD18610 and HHD18691 were constructed using the Maximum Likelihood method and K2 nucleotide substitution model with a gamma distribution (Kimura 1980). The bootstrap method was implemented for the accuracy estimation using 1000 bootstrap replicates (Felsenstein 1985).

\section{Results}

$\underline{\text { Taxonomic results }}$

$$
\begin{gathered}
\text { Phylum AsCOMYCOTA } \\
\text { Classis Pezizomycetes } \\
\text { Order Pezizales } \\
\text { Family Tuberaceae } \\
\text { Genbank No: MW423732, MW432548 }
\end{gathered}
$$$$
\text { Tuber macrosporum Vittad., } 1831 \text { (Figs 1-3) }
$$

\section{Morphological and microscopical features}

Fruitbodies $2-5$ (6) $\mathrm{cm}$ diameter, globose to subglobose, more or less cocooned furrowed, generally irregular in form, lobed, but also regular and subglobose, and reddish-brown to blackish brown, with flat, polygonal warts or a verrucous-areolate (Fig.1a).

Gleba compact, anthracite grey, grey-brown, brownlilac, finally purple-brown, thick, with thin, numerous interrupted white sterile veins, anastomosed, flaking on the peridium. It has a pleasant garlicky component and delicate perfume of fine white truffle and can be counted among the best edible truffles (Fig. 1b-d). 

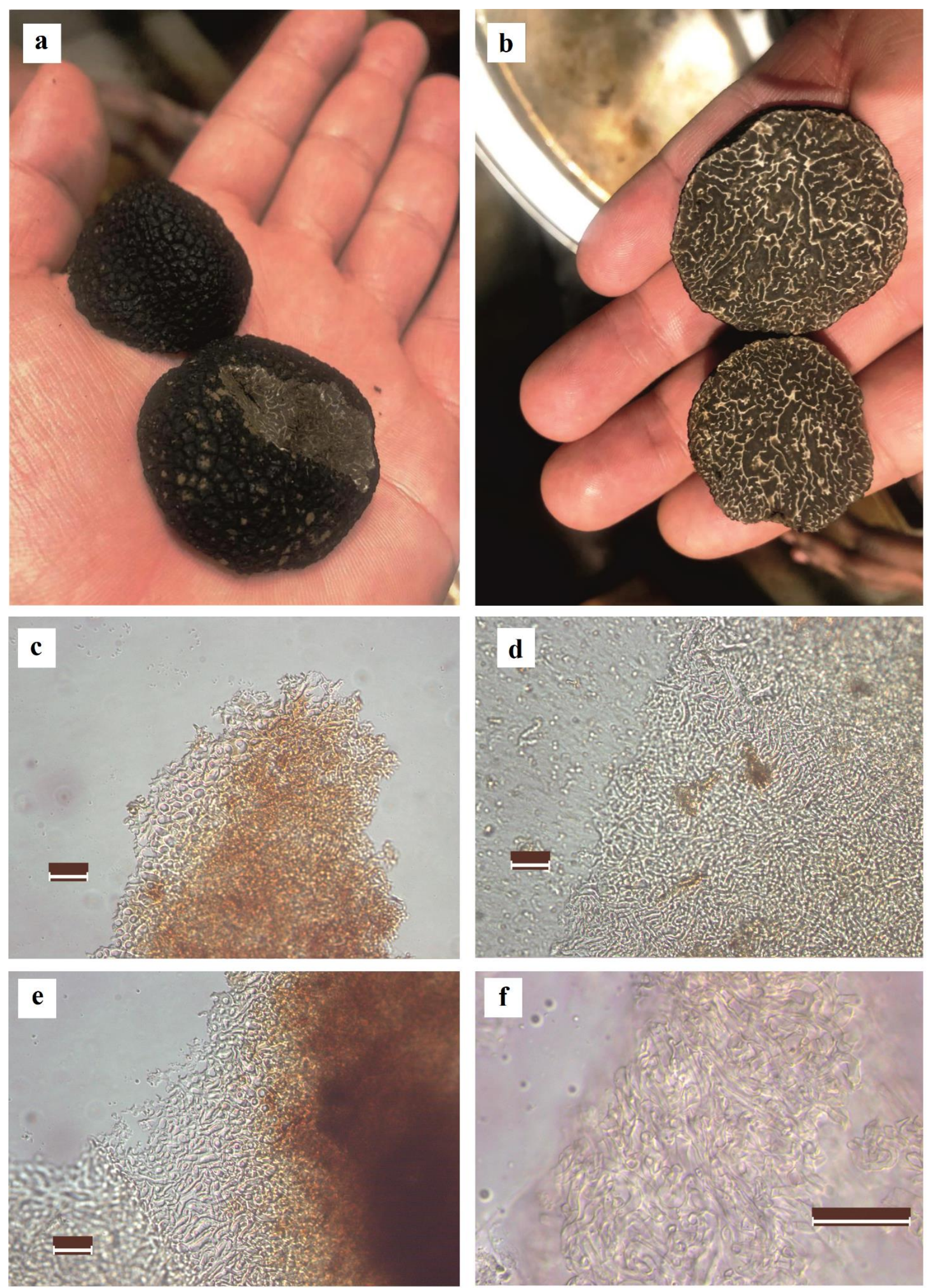

Fig. 1. T. macrosporm; a- macro-view of surface, b-macro-view of gleba-cross section, c-general microview of gleba, d-close-up microview of gleba, e- general microview of peridium, f- close-up microview of peridium. Scales $30 \mu \mathrm{m}$. 

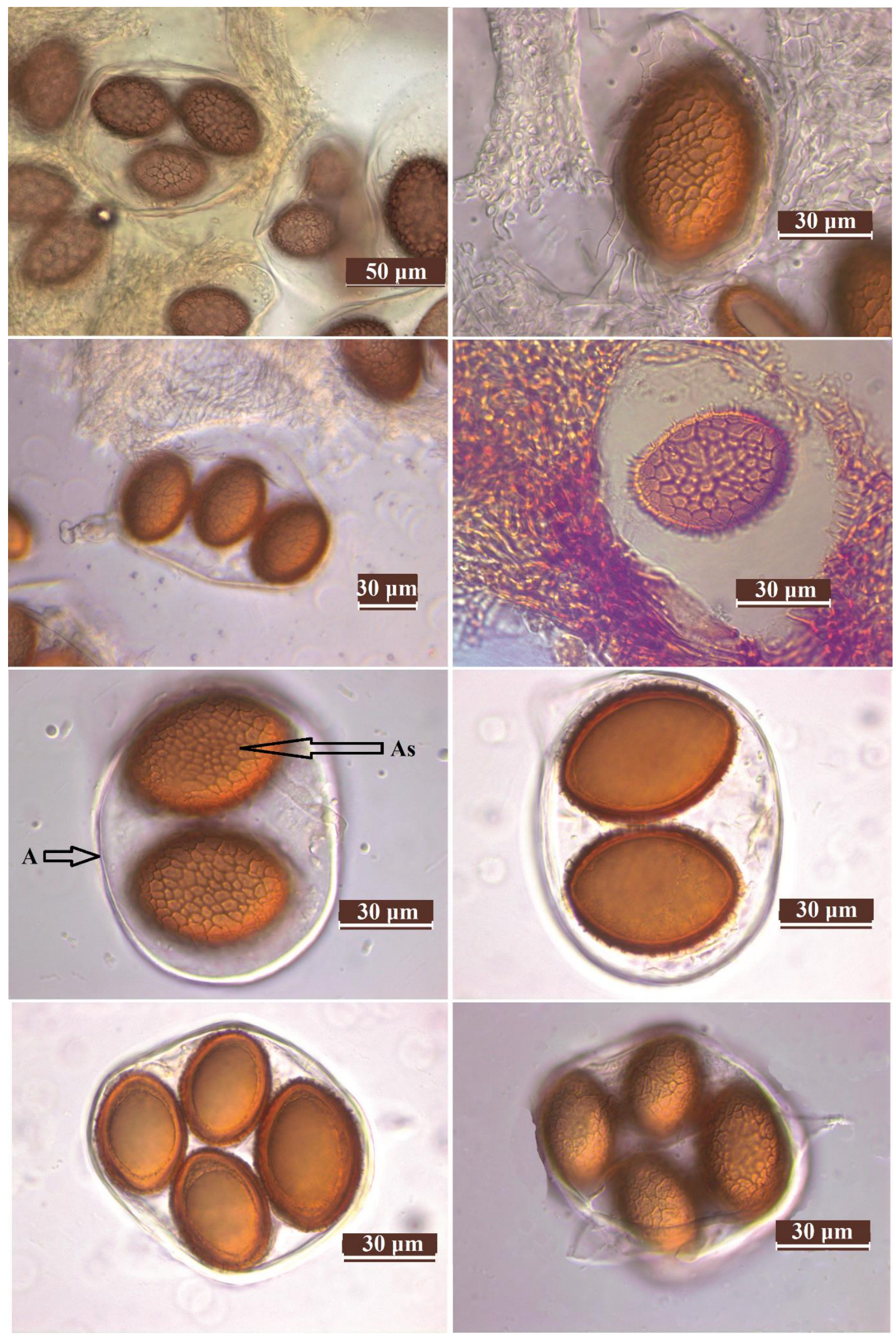

Fig. 2. Different views of Asci (indicated by an arrow, A) and ascospores (indicated by an arrow, As) under a light microscope. 


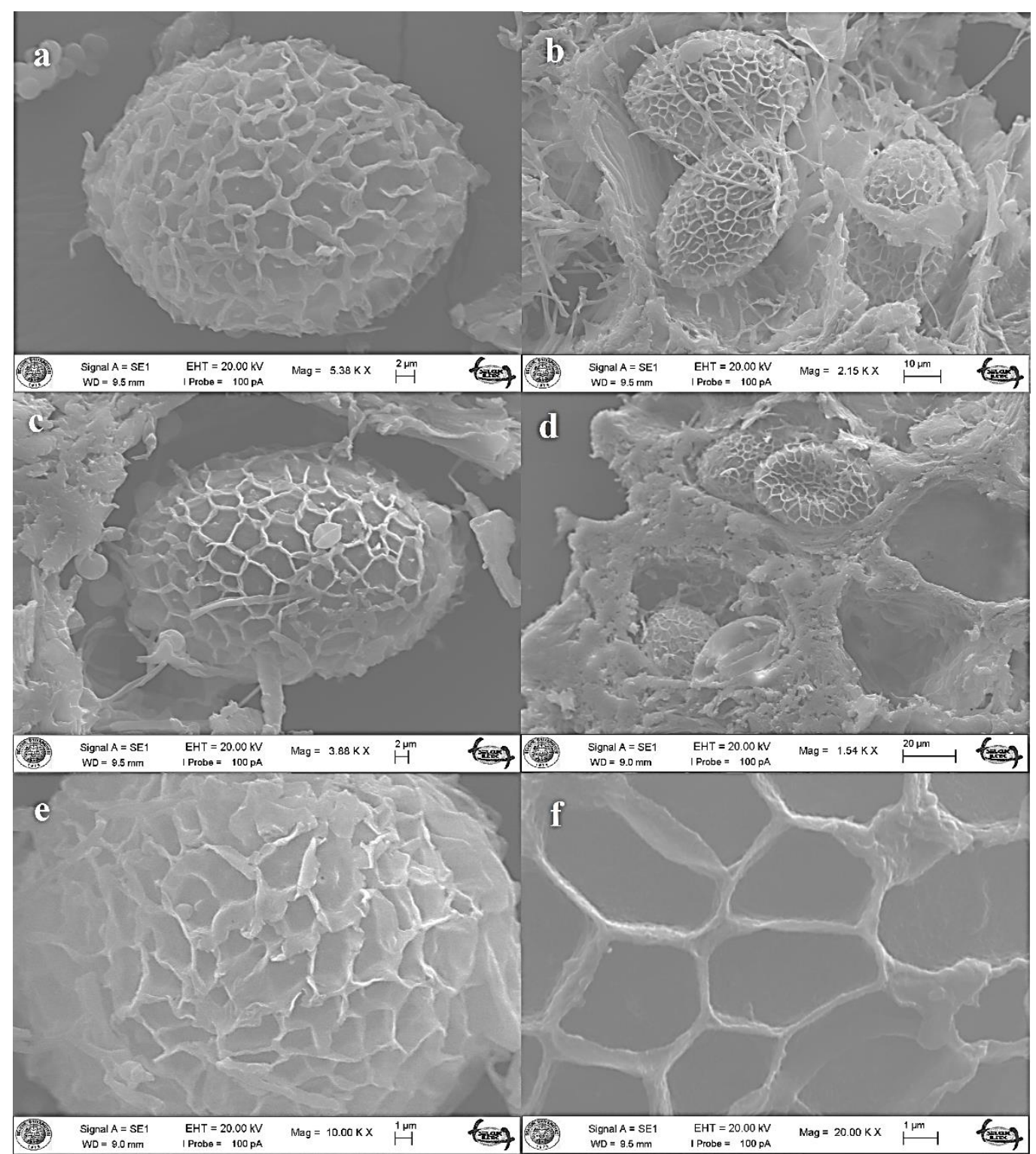

Fig. 3. SEM photograps; a, b-General views of ascospores, c-close-up views of the surface ornaments of ascospores, b-Asci.

Peridium very thin, $0.400-1 \mathrm{~mm}$, hyphal type, not separable. Composed of brown-black, irregularly polygonal, very short verrucous, flattened characteristically and very much variable in dimensions, sometimes absent and with a felty surface (Fig. 1e, f).

Asci subglobose to ellipsoid, with a short peduncle, 1-3 (4)-spored, mainly 3-spored, 90-120 x 60-80 $\mu \mathrm{m}$ (Figs 2, $3 b, d)$.

Ascospores strictly ellipsoidal tapered at the apex, cross-linked-packs, 2-2.5 (5) $\mu \mathrm{m}$ high and 8-12 $\mu \mathrm{m}$ long, brown-yellow, (25-)35-(45-)55 x (40-)45-(70-)85 $\mu \mathrm{m}, \mathrm{Q}$ $=1.6-1.7 \mu \mathrm{m}$ (Figs 2, 3a, b) with reticulate-alveolate irregular, polygonal meshes (Figs 2, 3c, e, f).

Species examined: Tekirdağ-Saray, in oak forest, under Quercus sp. 200 m, 14.IX.2017, HHD18610 (GenBank No: MW423732); Edirne-Meriç, Uzunköprü forest management chief area, Kadıdondurma Village, in oak forest, under Quercus sp., 150 m, 01.XII.2017, HHD18691 (GenBank No: MW432548).

\section{Molecular results}

In phylogenetic analysis of HHD18610 and HHD18691, 19 records of T. macrosporum were used to compare specimens similarity and 6 different Tuber species were used to show species differences. Terfezia boudieri Chatin. from the family Pezizaceae was selected for the outgroup (Fig. 4). The results showed that HD18610 and HD18691 showed high similarity in $T$. macrosporum sequences. While HD18610 showed high similarity with ANK Akata 7398 (unpublished data from Turkey), HHD18691 take place in a single line alone in the macrosporum group. The closest records to HHD18691 are NW1TMacro1 and ITA 011s. The BLAST analysis implemented with the nuclear ITS rDNA sequence of HHD18610 and HHD18691 revealed identity rates as high as $98-99 \%$ between the specimens and different isolates of T. macrosporum. 


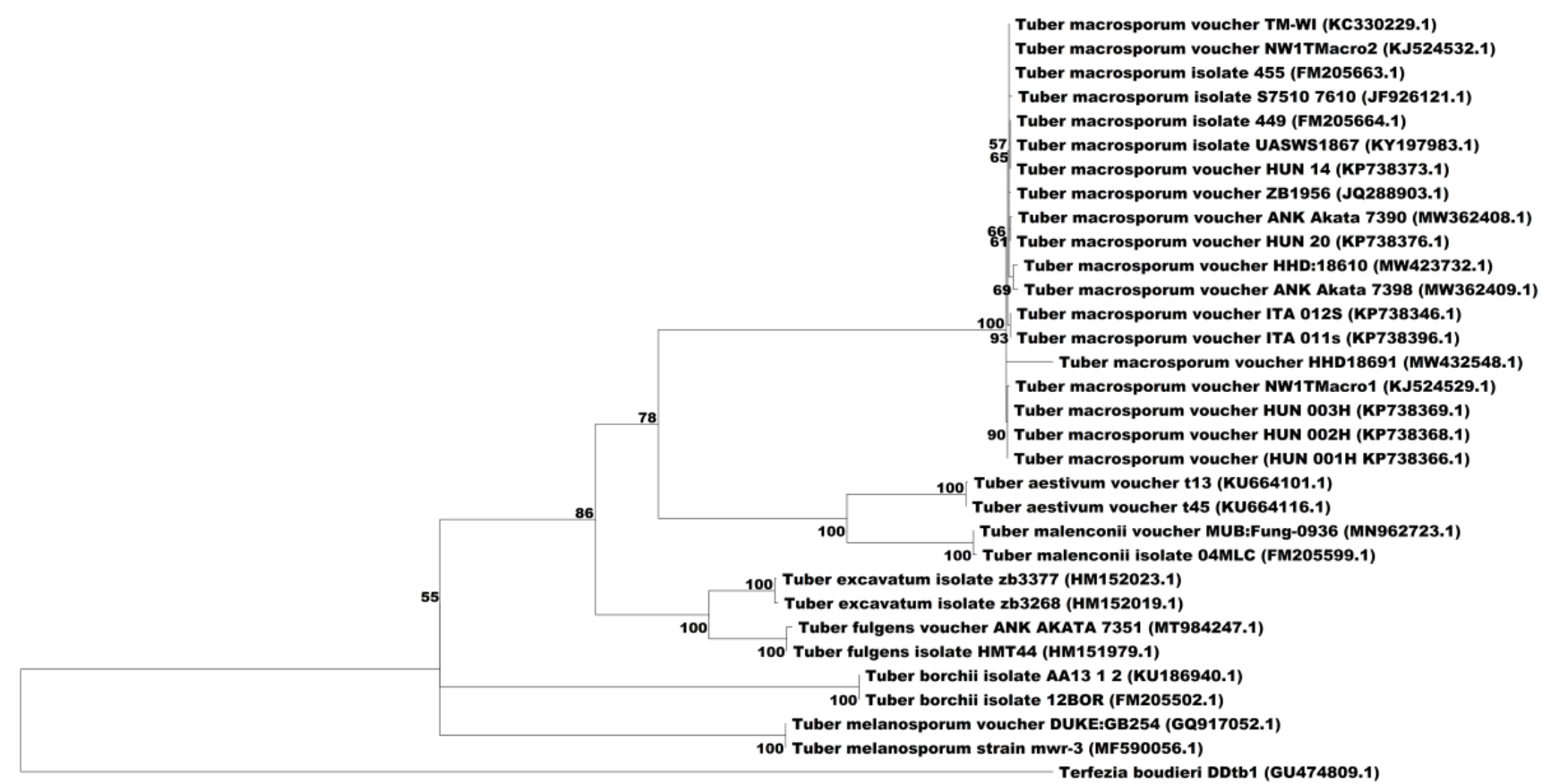

Fig. 4. The Maximum Likelihood tree revealing the phylogenetic relationships of 29 fungal sequences estimated from the nuclear ITS rDNA region. Percentage bootstrap values $(\geq 50)$ were indicated for each branch. Terfezia boudieri was included as the outgroup sample in the analysis. The scale bar (lower left) represents a genetic distance of 0.1 .

\section{Discussion}

Tuber macrosporum is a common species in European countries. So far it has been reported from the Czechia, Bulgaria, France, Hungary, Romania, Serbia, Switzerland, Ukraine, Italy and the United Kingdom where it is considered as rather rare (Hall et al. 2007). Recently, the species was found in Germany where it was considered to be extinct (Stobbe et al. 2012). T. macrosporum grows in an ectomycorrhizal symbiosis with many different tree species such as Fagus sylvatica L., Corylus avellana L., Quercus robur L., Pinus strobus L. and P. sylvestris L. (Granetti et al. 2005, Ławrynowicz et al. 2008). According to Bencivenga \& Baciarelli Falini (2012), C. avellana, Carpinus betulus L., Q. pubescens Willd. and Ostrya carpinifolia Scop. are the usual hosts of Tuber species in truffle orchards. The species prefers fresh, wet, occasionally flooded, thick, calcareous soils with variable levels of calcium carbonate, often in lowlands or near rivers (Vezzola 2005, Marjanović et al. 2009, Benucci et al. 2012). In Italy, fruiting bodies of the fungus are found in the same areas as Tuber magnatum Picco (white truffle) and have the same host plants (Hall et al. 2007). The time when the species fruits are not clearly defined, yet truffle collectors harvest $T$. macrosporum from August till December (Granetti et al. 2005).

The Thrace region creates a very suitable area for $T$. macrosporum. The forest structure generally consists of F. orientalis and oak species (Quercus hungarica
Hubeny, $Q$. cerris, $Q$. dschorochensis K.Koch and $Q$. pubescens) and soil properties are very suitable for the growth of T. macrosporum. Due to its very large spores, this species has never given rise to nomenclature or synonymy problems. Amateur collectors can sometimes confuse it with $T$. aestivum (the black truffle). Having bigger spores than in any other similar species, the very short and flat verrucous (similar to crusts) in many cases absent and with a felty surface in exoperidium less than $T$. aestivum, as well as having a pungent garlic smell are the main characters which enable to give it a precise and correct determination. The good and garlicky odour, reminding of T. magnatum, makes this species the best of the so-called black truffles, according to many gourmets.

\section{Acknowledgement}

I would like to thank Ziyafet Arslan for his valuable effort he made during the field studies.

Ethics Committee Approval: Since the article does not contain any studies with human or animal subject, its approval to the ethics committee was not required.

Conflict of Interest: The authors have no conflicts of interest to declare.

Funding: This study was supported by Selçuk University, Scientific Research Projects Coordinating Office (BAP/20401081). 


\section{References}

1. Akata, I., Sevindik, M. \& Şahin, E. 2020. Tuber fulgens Quél. A New record for Turkish truffles. Turkish Journal of Agriculture-Food Science and Technology, 8(11): 24722475 .

2. Alkan, S., Aktaş, S. \& Kaşık, G. 2018. Türkiye'deki Tuber türleri ve Tuber aestivum için yeni bir lokalite. Selçuk Üniversitesi Fen Fakültesi Fen Dergisi, 44(1): 25-29.

3. Astier, J. 1998. Truffes Blanches et Noires (Tuberaceae \& Terfeziaceae). Louis-Jean, 127 pp.

4. Bencivenga, M. \& Baciarelli Falini, L. 2012. Manuale di Tartuficoltura. Esperienze di Coltivazionedei Tartufi in Umbria. Assessorato Regionale Agricoltura e Foreste, Regione Umbria, 137 pp.

5. Benucci, G.M.N., Goga Csorbai, A., Di Massimo, G., Baciarelli Falini, L., Bencivenga, M. \& Donini, D. 2012. Mycorrhization of Quercus robur L. and Corylus avellana L. seedlings with Tuber macrosporum Vittad. Mycorrhiza, 22(8): 639-646.

6. Breitenbach, J. \& Kränzlin, F. 1983. Fungi of Switzerland: Vol.1. Ascomycetes. Verlag Mykologia, Luzern, 310 pp.

7. Castellano, M.A. \& Türkoğlu, A. 2012. New records of truffle taxa in Tuber and Terfezia from Turkey. Turkish Journal of Botany, 36(3): 295-298.

8. Elliott, T.F., Türkoğlu, A., Trappe, J.M. \& Yaratanakul, G.M. 2016. Turkish truffles 2: eight new records from Anatolia. Mycotaxon, 131: 439-453.

9. Felsenstein, J. 1985. Confidence limits on phylogenies: An approach using the bootstrap. Evolution, 39: 783-791.

10. Gezer, K., Kaygusuz, O., Çelik, A. \& Iş̧loğlu, M. 2014. Ecological characteristics of truffles growing in Denizli Province, Turkey. Journal of Food, Agriculture \& Environment, 12(2): 1105-1109.

11. Gori, L. 2005. Funghi Ipogei Della Lucchesia di Aitre Province Italiane e dall' Estero. Pacini Fazzi, 316 pp.

12. Granetti, B., De Angelis, A. \& Materozzi, G. 2005. Umbria, Terra di Tartufi. Regione Umbria-Gruppo Micologico Ternano, Terni, 303 pp.

13. Hall, I., Brown, G. \& Zambonelli, A. 2007. Taming the Truffle. The history, Lore, and Science of the Ultimate Mushroom. Timber Press, Oregon, 304 pp.

14. Kaya, A. 2009. Macromycetes of Kahramanmaraş province (Turkey). Mycotaxon, 108: 31-34.

15. Kimura, M. 1980. A simple method for estimating evolutionary rate of base substitutions through comparative studies of nucleotide sequences. Journal of Molecular Evolution, 16: 111-120.

16. Kumar, S., Stecher, G., Li, M., Knyaz, C. \& Tamura, K. 2018. MEGA X: molecular evolutionary genetics analysis across computing platforms. Molecular Biology and Evoluation, 35: 1547-1549.

17. Ławrynowicz, M., Krzyszczyk, T. \& Fałdziński, M. 2008. Occurrence of black truffles in Poland. Acta Mycologica, 43(2): 143-151.
18. Marjanović, Ž., Grebenc, T., Marković, M., Glišić, A. \& Milenković, M. 2010. Ecological specificities and molecular diversity of truffles (genus Tuber) originating from mid-west of the Balkan Peninsula. Sydowia, 62(1): 67-87.

19. Medardi, G. 2006. Ascomiceti d'Italia Atlante Fotografico. Fondazione Centro Studi Micologici Dell'A.M.B., Vicenza, $678 \mathrm{pp}$.

20. Medardi, G. 2012. Atlante Fotografico Degli Ascomiceti d'Italia. Fondazione Centro Studi Micologici Dell'A.M.B. Vicenza, 454 pp.

21. Montecchi, A. \& Sarasini, M. 2000. Funghi Ipogei d'Europa. Associazione Micologica Bresadola, Trento, 714 pp.

22. Öztürk, C., Kaşık, G. \& Toprak, E. 1997. Ascomycetes makrofunguslarından Türkiye için iki yeni kayit. Ot Sistematik Botanik Dergisi, 4: 53-56.

23. Pegler, D.N., Spooner, B.M. \& Young, T.W.K. 1993. British Truffles: A revision of British Hypogeous fungi. The Royal Botanic Gardens, Kew, 216 pp.

24. Sesli, E., Asan, A., Selçuk, F. (eds.), Abacı Günyar, Ö., Akata, I., Akgül, H., Aktaş, S., Alkan, S., Allı, H., Aydoğdu, H., Berikten, D., Demirel, K., Demirel, R., Doğan, H.H., Erdoğdu, M., Ergül, C.C., Eroğlu, G., Giray, G., Haliki Uztan, A., Kabaktepe, Ş., Kadaifçiler, D., Kalyoncu, F., Karaltı, İ., Kaşık, G., Kaya, A., Keleş, A., Kırbağ, S., Kıvanç, M., Ocak, İ., Ökten, S., Özkale, E., Öztürk, C., Sevindik, M., Şen, B., Şen, İ., Türkekul, İ., Ulukap1, M., Uzun, Ya., Uzun, Yu. \& Yoltaş, A. (2020). Türkiye Mantarları Listesi. Ali Nihat Gökyiğit Vakfı Yayın1. İstanbul, 1192 pp.

25. Şen, I., All1, H. \& Civelek, H.S. 2016. Checklist of Turkish truffles. Turkish Journal of Life Sciences, 1(2): 103-109.

26. Stobbe, U., Büntgen, U., Sproll, L., Tegel, W. \& Egli, S. 2012. Spatial distribution and ecological variation of rediscovered German truffle habitats. Fungal Ecology, 5(5): 591-599.

27. Thompson, P.I. 2013. Ascomycetes in Colour: Found and Photographed in Mainland Britain. Xlibris, Lexington KY, 408 pp.

28. Trappe, M., Evans, F. \& Trappe, J. 2007. Field Guide to North American Truffles: Hunting, Identifying, and Enjoying the World's Most Prized Fungi. Ten Speed Press, Berkeley, Toronto, $136 \mathrm{pp}$.

29. Trappe, J.M., Molina, R., Luoma, D.L., Cázares, E., Pilz, D., Smith, J.E., Castellano, M.A., Miller, S.L. \& Trappe, M.J. 2009. Diversity, Ecology and Conservation of Truffle Fungi in Forests of the Pacific Northwest. United States Department of Agriculture Forest Service Pacific Northwest Research Station General Technical Report PNW-GTR-772, USA, 202 pp.

30. Türkoğlu, A. \& Castellano, M.A. 2014. New records of some Ascomycete truffle fungi from Turkey. Turkish Journal of Botany, 38: 406-416.

31. Türkoğlu, A., Castellano, M.A., Trappe, J.M. \& Yaratanakul, G.M. 2015. Turkish truffles I: 18 new records for Turkey. Turkish Journal of Botany, 39: 359-376. 
32. Uzun, Y. \& Yakar, S. 2018. New locality record for two Tuber species in Turkey. Anatolian Journal of Botany, 2(2): 88-92.

33. Vezzola, V. 2005. Primi Risultati Produttivi Con Piante Micorrizate da T. macrosporum Vittad., 51-55, Paper presented at the Atti Seminario Sullo Stato Attuale Della Artuficoltura Italiana. 21 Febbraio, Spoleto-Italy.
34. White, T.J., Bruns, T., Lee, S. \& Taylor, J. 1990. Amplification and direct sequencing of fungal ribosomal RNA genes for phylogenetics. Pp. 315-322. In: Innis M.A., Gefland D.H., Sninsky J.J. \& White T.J. (eds). PCR Protocols: A Guide to Methods and Applications. Academic Press Inc., New York, 482 pp. 